\title{
Compressive strength in Heartwood Extract of Teak (HWE) treated hardwoods after exposure to white rot attack
}

\author{
S.O. OLAJUYIGBE, O.Y. OGUNSANWO * and A.O. ADEGEYE
}

Department of Forest Resources Management, University of Ibadan, Nigeria.

*Corresponding author,E-mail:ogunsanwokay@yahho.com,oy.ogunsanwo@mail.ui.edu.ng

\begin{abstract}
Wood samples of Triplochiton scleroxylon and Gmelina arborea obtained from Omo Forest Reserve, South West Nigeria were treated with Heartwood Extract of Teak (HWE) and cuprinol-clear. The wood blocks were inoculated with two white rot fungi; Pleurotus squarrosullus and Lentinus subnudus for 12 weeks. Absorption of chemicals were determined at two concentration levels while resistance to decay was tested using Maximum Compressive Strength parallel to grain (MCS//). Data obtained were analyzed using ANOVA and descriptive statistics. Within wood blocks of the same species, absorption of both HWE and cuprinol-clear were not significantly different at both $4 \%$ and $8 \%$ concentrations. In both preservatives G.arborea test bocks produced higher MCS// than test blocks of T. scleroxylon. HWE was effective in reducing the impact of white rot in Gmelina arborea and Triplochiton scleroxylon.

(C) 2010 International Formulae Group. All rights reserved.
\end{abstract}

Keywords: Heartwood extract, Gmelina arborea, Triplochiton scleroxylon, White rot fungi, Compressive strength.

\section{INTRODUCTION}

Wood being organic in origin is prone to decay by the action of the environment and biological agents, which invade it for shelter and nutrition (Bryan et al., 1991; Dhyani and Tripathi, 2006; Morris, 1998; Sarker et al., 2006). In Nigeria and other parts of the world, research works have focused on alternative chemicals to the proprietary preservatives, such as pentachlorophenol, lindane, dieldrin and chromated copper arsenate salts (CCA) (Sundman 1990; (Adetogun and Adegeye, 2002).

New preservatives are currently being developed and marketed in response to active public concern about negative environmental effects of preservatives containing arsenic and chromium elements. Preservative treatment methods are usually applied by pressure and non-pressure methods. None however confers complete immunity as a treatment considered suitable for one particular set of conditions may be useless for others. The performance of preservatives in treated wood depends on many factors, among which are the amount of preservative absorbed by the wood, the depth to which it penetrates into the wood and the uniformity of penetration. For quality assurance, it is important to know the amount of fungicide applied to wood, although fungicide at an apparently known concentration can be applied to wood, it is the amount of chemicals retained in the wood that determines, whether or not fungi would grow. Thus, knowing the actual threshold level of wood inhabiting fungi is crucial (FAO 1986; Usta et al., 2006). 
Most of the commercially available preservatives, such as CCA and Pentachlorophenol preservatives, being synthetic in nature, pose a great difficulty during the disposal of timber treated with them. At the same time posing danger to the health of workers engaged in treating plants and a threat to the environment when leached out (Onuorah, 2001).

Wood extractives are extraneous components of the trees (Akpofure, 1992) which are natural chemicals that proffer resistance against decay in wood (Prestemon, 1994). Studies have shown that injecting wood extractives of durable species into non-durable specimen increases the wood samples' durability (Ogunsanwo et al., 2006; Kazemi et al., 2006). It is therefore, pertinent to harness knowledge on the potent heartwood extractives of durable timbers for the development of novel environmental friendly wood protecting chemicals. This study is therefore aimed at investigating the efficacy of Heartwood Extract of Teak (HWE) as a preservative against wood decaying fungi.

\section{MATERIALS AND METHODS}

The wood samples of Triplochiton scleroxylon and Gmelina arborea were taken from felled tree samples from Omo Forest Reserve, South western Nigeria. The wood samples were sawn into sizes of $6 \mathrm{~cm} \times 2 \mathrm{~cm} \times 2$ $\mathrm{cm}$ and the cutting was so arranged that the grains of the wood followed the long axis using (BSI, 1961)

Before starting the test the blocks were dried and sterilized in an oven for 18 hours at $103{ }^{\circ} \mathrm{C}$. The weight was recorded as initial dry weight for each of the blocks. Four hundred test blocks for each species were dried and labeled T1-T400 (Triplochiton scleroxylon) and G1G400 for (Gmelina arborea).

Heartwood portions of Tectona grandis were chipped, milled to fine dust, weighed and then collected in plastic bags. Five hundred (500 g) was extracted in soxhlet apparatus in absolute ethanol in accordance with the T2 0403-76 standard (Kazemi et al., 2006). The absolute ethanol-extractive mixture was collected and evaporated in vacuo using a rotary evaporator. The mixture and the pasty HWE liquid in 500 $\mathrm{ml}$ round bottom flask were heated at $78{ }^{\circ} \mathrm{C}$ at 7 rpm for 5 days. The absolute ethanol was later collected in $100 \mathrm{ml}$ round bottom flask while the oily HWE extractive remained in the $500 \mathrm{ml}$ round bottom flask. The volume-to-volume method (Adetogun and Adegeye, 2002) was used to dissolve the HWE extractive in kerosene. Concentration levels of $4 \%$ and $8 \%$ were prepared for the two preservatives. Thus, the following solutions were prepared $\mathrm{C}_{1}: 8 \%$ cuprinol-clear solution, $\mathrm{C}_{2}: 4 \%$ cuprinol-clear, $\mathrm{C}_{3}: 8 \%$ HWE, $\mathrm{C}_{4}: 4 \%$ HWE, $\mathrm{C}_{5}$ : Pure kerosene.

A non-pressure dipping method according to Odeyinde, 1986; and FAO, 1986 was used for treatment of the wood test blocks with the preservative and HWE. Wood samples were completely immersed in HWE for 10 minutes at room temperature. After treatment, the blocks were drained and dried in the laboratory and then reweighed to determine the level of absorption as follows:

$\operatorname{Abs}\left(\mathrm{kg} / \mathrm{m}^{3}\right)=\frac{10^{6} \times \text { WPA }}{1000 \times \mathrm{VW}}$

where Abs = Absorption, WPA $=$ weight of preservative absorbed, $\mathrm{VW}=$ volume of wood.

\section{Culture medium}

The inoculums of Pleurotus squarrosullus and Lentinus subnudus in Potato Dextrose Agar (PDA) were prepared. First the PDA (35 g) was mixed with 1 liter of water in conical flask and then homogenized; $40 \mathrm{ml}$ of PDA was then poured into McCartney bottles and sterilized by autoclaving at $0.1 \mathrm{~N} / \mathrm{mm}^{2}(120$ ${ }^{\circ} \mathrm{C}$ ) for of 20 minutes. After sterilization the flask were laid sideways so that the medium is retained in the neck of the bottle. The medium was inoculated with the test fungi within 6 days after preparation of the bottles (Sarker et al., 2006). The bottles were then incubated at room temperature $\left(27 \pm 2{ }^{\circ} \mathrm{C}\right)$ in the laboratory. 


\section{Infection of test blocks}

The inoculation of the test blocks was done by placing them aseptically in bottles in which there are actively growing cultures of the test fungi. The blocks were placed such that they came in contact with the aerial mycelium of the fungus and not the medium, itself, to prevent leaching of the preservatives (Sarker et al., 2006). Four test blocks treated at each dilution level (4 and $8 \%$ cuprinol-clear, 4 and $8 \%$ HWE), one block treated with kerosene and another block as control were placed in bottles containing each of the two test fungi. Before the inoculation of the control (untreated) test blocks these samples were wrapped in aluminum foil and sterilized in the oven.

\section{Incubation and duration of the test}

The bottles containing the test blocks were incubated at $27 \pm 2{ }^{\circ} \mathrm{C}$ for $2,4,6,8,10$ and 12 weeks. At the end of each incubation period, the blocks were removed from the culture bottles, and weighed to determine moisture absorbed. The weighed samples were oven-dried at $103{ }^{\circ} \mathrm{C}$ to constant dry weight before compression test (Sarker et al., 2006).

\section{Compression test}

A Hounsfield tensometer was used to determine the Maximum Compressive Strength (MCS), parallel to grain, of each sample. All the test blocks were oven dried to constant dry weight before conducting the test. The test blocks were loaded at machine speed of $0.01 \mathrm{~mm}$ per second until failure occurred. Forty eight test blocks were removed from the inoculation bottles for testing at a 2-weekly interval.

\section{Data Analysis}

The data obtained were analyzed using a Multi-factorial Analysis of Variance ANOVA. Means were separated with the aid of Least Significant Difference LSD at 5\% level of significance. The general linear model (GLM) of statistical analysis of variance was used to determine variations within and between factors. The factors considered were as indicated below:
Test blocks at 2 levels; (T. scleroxylon (Obeche) $\mathrm{A}_{1}$ and G. arborea (Gmelina) $\mathrm{A}_{2}$ )

Test fungi at 2 levels; (Lentinus subnudus $\mathrm{F}_{1}$ and Pleurotus squarrosulus $\mathrm{F}_{2}$ )

Chemical concentration at 6 levels: $\mathrm{C}_{1}=$ $8 \%$ cuprinol-clear, $\mathrm{C}_{2}=4 \%$ cuprinol-clear, $\mathrm{C}_{3}=$ $8 \%$ HWE, $\mathrm{C}_{4}=4 \%$ HWE, $\mathrm{C}_{5}=$ Kerosene, $\mathrm{C}_{6}=$ Control

Period of inoculation (week): 2, 4, 6, 8, 10, and 12

\section{RESULTS}

Absorption of chemical preservatives Absorption of preservatives was generally higher in $T$. scleroxylon wood samples than in $G$. arborea. For instance, between $54.86-64.9 \mathrm{~kg} / \mathrm{m}^{3}$ of HWE was absorbed by $T$. scleroxylon while between $24.0-37.8 \mathrm{~kg} / \mathrm{m}^{3}$ was absorbed by G. arborea. Similarly, $60.80-67.30 \mathrm{~kg} / \mathrm{m}^{3}$, and $34.6-38.3$ $\mathrm{kg} / \mathrm{m}^{3}$, of cuprinol were absorbed by $T$. scleroxylon and G. arborea respectively, table 1. The analysis of variance indicated that there were no significant differences in absorption of preservatives by wood samples from the two species at lower concentrations, postmortem analysis. Table 2, however, showed differences among concentration levels in the two types of preservatives. Also, marked differences however existed in the manner of absorption of preservative by the species. In $T$. scleroxylon, absorption of HWE was significantly higher $(\mathrm{P}<0.05)$ at lower concentrations, while the reverse was the case for cuprinol absorption. Conversely, absorption of preservatives increased from lower to higher concentrations in G. arborea, but the increase were generally not statistically significant.

\section{Efficacy of preservatives using Maximum Compressive Strength (MCS) parallel to grain \\ Variations in the strength property of wood samples treated with HWE and cuprinol are illustrated in Figures 1 and 2. As shown in the figures, G. arborea wood blocks exposed}


to both Lentinus subnudus and Pleurotus squarrosullus had higher MCS// (35.60-25.90 $\mathrm{N} / \mathrm{mm}^{2}$ ) than samples from $T$. scleroxylon $\left(28.95-20.55 \mathrm{~N} / \mathrm{mm}^{2}\right)$. Also in G. arborea, higher MCS// were achieved at higher concentrations of cuprinol clear as against the trend in T. scleroxylon. Conversely, increase in concentration of HWE resulted in decreased MCS// of test blocks of $T$. scleroxylon and increased MCS// of $G$. arborea test blocks. Although, activities of the two fungi types were not statistically significant, results showed that cuprinol-clear was more effective on $L$. subnudus than $P$. squarrosullus in G. arborea at both $4 \%$ and $8 \%$ concentration levels. On the other hand, HWE treated blocks had $24.55 \mathrm{~N} / \mathrm{mm}^{2}$ and
$26.30 \mathrm{~N} / \mathrm{mm}^{2}$ after exposure to $P$. squarrosullus as against $21.44 \mathrm{~N} / \mathrm{mm}^{2}$ and $23.20 \mathrm{~N} / \mathrm{mm}^{2}$ for $T$. scleroxylon blocks exposed to L. subnudus. The results further showed that $G$. arborea treated with pure kerosene had MCS// of $28.2 \mathrm{~N} / \mathrm{mm}^{2}$ and 25.9 $\mathrm{N} / \mathrm{mm}^{2}$, while $T$. scleroxylon blocks had 23.4 $\mathrm{N} / \mathrm{mm}^{2}$ and $20.55 \mathrm{~N} / \mathrm{mm}^{2}$ respectively for $L$. subnudus and $P$. squarrosullus.

The analysis of variance indicated that wood species and preservative type had significant effects on MCS// while fungi type had no effect at 0.05 probability level. Furthermore, first order interactions between factors indicated that species $\mathrm{X}$ preservative and preservative $\mathrm{X}$ period of exposure were all statistically significant.

Table 1: Absorption $\left(\mathrm{Kg} / \mathrm{m}^{3}\right)$ of the preservatives by the two hardwood species

\begin{tabular}{cccc}
\hline Preservative concentration & \multicolumn{2}{c}{ Wood species } \\
\hline & & G. arborea & T. scleroxylon \\
\hline HWE & $4 \%$ & $24.0 \pm 1.03$ & $64.9 \pm 3.16$ \\
\cline { 3 - 4 } & $8 \%$ & $37.8 \pm 2.20$ & $54.86 \pm 2.01$ \\
\hline Cuprinol & $4 \%$ & $34.6 \pm 2.67$ & $67.3 \pm 2.33$ \\
\hline & $8 \%$ & $38.31 \pm 71$ & $60.80 \pm 2.14$ \\
& & & \\
& & &
\end{tabular}

$\mathrm{N}=60$ for all species; HWE $=$ Heartwood Extract of Teak

Table 2: Results of follow up tests (Least significant differences) for mean values of absorption of preservatives by $T$. scleroxylon and $G$. arborea test blocks.

\begin{tabular}{lcc}
\hline Chemical preservative & T. scleroxylon $\left(\mathbf{k g} / \mathbf{m}^{\mathbf{3}}\right)$ & G. arborea $\left(\mathbf{k g} / \mathbf{m}^{\mathbf{3}}\right)$ \\
\hline 4\% Cuprinol-clear & $67.30 \mathrm{a}$ & $20.27 \mathrm{a}$ \\
4\% HWE & $64.94 \mathrm{a}$ & $24.01 \mathrm{a}$ \\
8\% Cuprinol-clear & $60.80 \mathrm{ab}$ & $27.26 \mathrm{a}$ \\
8\% HWE & $54.86 \mathrm{~b}$ & $24.55 \mathrm{a}$ \\
& & \\
\hline
\end{tabular}

Note: Means with the same letter are not significantly different at $\alpha=0.05 ; \mathrm{HWE}=$ Heartwood Extract of Teak 


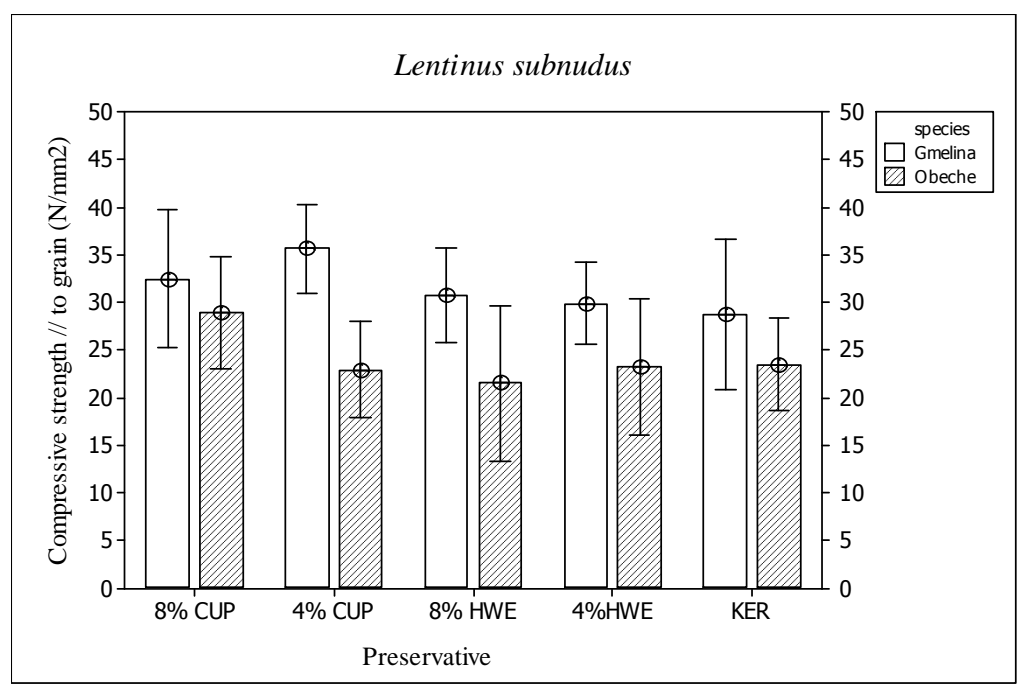

Figure 1: Variations in compression strength parallel to grain in wood blocks exposed to Lentinus subnudus.

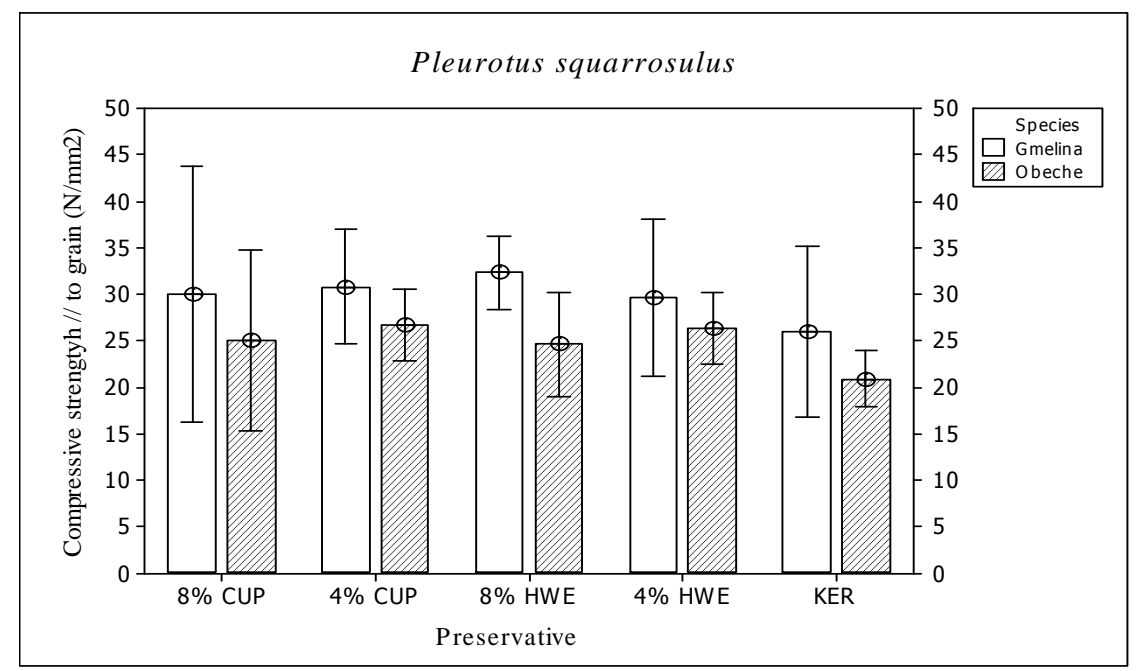

Figure 2: Variations in compression strength parallel to grain in wood blocks exposed to Pleurotus squarrosullus.

\section{DISCUSSION}

Wood samples from $T$. scleroxylon absorbed the chemicals more at lower concentrations indicating that wood samples from the species were easily impregnated with the preservatives by dipping, thus supporting permeability coding of this wood species as suggested by Adetogun and Adegeye (2002).

The higher rate of absorption by $T$. scleroxylon test blocks when compared to Gmelina test blocks may be due to higher porosity of $T$. scleroxylon as against $G$. arborea with lower permeability. Owoyemi and Kayode 
(2008), while working on the effect of incision on preservative absorption capacity of Gmelina arborea had pointed out that $G$. arborea is resistant to oil and water borne preservatives even when treated with vacuum and hot treatment methods. The difference observed between the two species is likely to be due to the difference in their wood anatomic characteristics as earlier asserted by Kazemi et al. (2006) and Viitanen et al. (2006), that durability and porosity are influenced by wood microstructure and chemical composition. The high absorption of $T$. scleroxylon $\left(67.30 \mathrm{~kg} / \mathrm{m}^{3}\right)$ differ from the results achieved by Omole and Onilude (2000); where the absorption of spent engine oil by $T$. scleroxylon was $24.9 \mathrm{~kg} / \mathrm{m}^{3}$. This was also suppported by Temiz and Yildiz (2006), who attributed differences to the chemical constituents of the preservatives.

G. arborea wood blocks exposed to both Lentinus subnudus and Pleurotus squarrosullus had higher MCS// than treated blocks of $T$. scleroxylon. This result was expected, as reports from Onilude and Ogunsanwo, 2002, already showed that untreated small clear specimens of $T$. scleroxylon had MCS// lower than samples from G. arborea. Higher MCS// achieved at higher concentrations of cuprinol clear for $G$. arborea is in tandem with report of other researchers working on woods (Adetogun et al., 2003; Yildiz et al., 2004; Yildiz and Temiz, 2006) and this is due largely to increased absorption of preservatives which might have resulted in improved resistance to fungi attack. Decreasing trends in strength properties of treated wood samples as shown by $T$. scleroxylon wood blocks in this study had been reported by Tascioglu et al. (2002), it is believed that high concentration of preservative in wood may produce a degrading effect rather than improving its resistance to agents of biodeterioration. It is interesting to note that $100 \%$ increase in concentration of HWE significantly reduced MCS// of T. scleroxylon test blocks while that of $G$. arborea increased. For G. arborea, the likelihood of HWE producing mild effects which may not be strong enough to neutralize the biocide effect of the extract on the wood. The higher absorption of HWE of $T$. scleroxylon at low concentration might be responsible for the higher MCS// recorded, suggesting that HWE of teak may be applied at low concentrations without compromising its ability to impart resistance to wood.

Though the effect of fungi type were not significant on MCS// in both wood species, it should be noted that cuprinol-clear was more effective on L.subnudus than $P$. squarrosullus in $G$. arborea while $P$. squarrosullus was more effective in protecting T. scleroxylon.

\section{Conclusions}

Absorption of heartwood extract HWE of teak and that of the conventional preservative cuprinol-clear are similar in wood blocks of $G$. arborea and $T$. scleroxylon. The study was able to show that effect of concentration of HWE on fungal activities will be determined by the species being preserved. It was further shown from Maximum Compressive Strength parallel to grain (MCS//) test, that L. subnudus was best controlled with $8 \%$ cuprinol-clear, while $8 \%$ HWE was most effective against $P$. squarrosullus in G. arborea. In $T$. scleroxylon, the two fungi were best controlled at $4 \%$ concentration of HWE. Heartwood extract of teak has the potential to protect non durable hardwoods against white rot fungi.

\section{REFERENCES}

Adetogun AC, Adegeye AO. 2002. Aqueous leaching of cashew nut shell liquid (CNSL) treated wood of Triplochiton scleroxylon K. Schum exposed to basidiomycetes decay fungi. Journal of Tropical Forest Resources, 18: 69-74.

Adetogun AC, Aina OM, Ogunsanwo OY. 2003. Evaluation of cashew nut shell liquid (CNSL) as wood preservative using 
crushing strength. Asset Series A., 3 (4): 5561.

Akpofure E. 1992. Variation in extractive and mineral contents and wood density of some mangrove tree species in Nigeria. MSc project. Department of Forest Resources Management. University of Ibadan, Nigeria. $238 \mathrm{p}$.

Bryan HR, Vick CB, Gillespie RH. 1991. Wood as an Adherent. Treatise on Adhesion and Adhesives (Vol. 7). Minford JD (ed.). Marcel Dekker Inc: New York.

BSI. 1961. British Standard Institute: Methods of test for toxicity of wood preservatives to fungi. BS838 London, England.

Dhyani S, Tripathi S. 2006. Protection of hard and softwood through Neem leaves extracts and oil: A direction towards development of eco-friendly wood preservatives. The International Research Group On Wood Preservation, Document No. IRG/WP0620394. Paper for the $37^{\text {th }}$ Annual Meeting, Tromso: Norway; 18-22.

FAO. 1986. Wood preservation manual. FAO Forestry Paper 76; 152p.

Kazemi SM, Hosinzadeh A, Rezaii MB. 2006. The effect of woody and non-woody plants extractives on microbial resistance of nondurable species. The International Research Group On Wood Preservation, Doc. No. IRG/WP06-20392. Paper for the $37^{\text {th }}$ Annual Meeting, Tromso: Norway; 18-22.

Odeyinde MA. 1986. Decay process in hardwood window frames and its control measures. PhD. Thesis. Department of Agricultural and Wood Engineering. University of Ibadan, Ibadan, Nigeria. p 191.

Ogunsanwo OY, Adetogun AC. Ogunbiyi AO. 2006. Preliminary investigation on the efficacy of wood extract of Teak Tectona grandis as preservative against wood decay: Proceeding of ECOWOOD 2006 Conference, Portugal.

Omole AO, Onilude MA. 2000. Study on use of engine oil as wood preservative. Journal of Tropical Forest Resources, 16(1): 66-71.
Onilude MA, Ogunsanwo OY. 2002. Mechanical properties of plantation grown obeche (Triplochiton scleroxylon) and their relationships with wood specific gravity. Journal of Tropical Forest Products, 8(2) 160-167.

Onuorah EO. 2001. The efficacy of heartwood extracts of Afzelia africana and Erythrophelum suaveolens as wood preservatives. Journal of Timber Development Association (India), 47 (1-2): 1-20.

Owoyemi JM, Kayode JO. 2008. Effect of incision on preservative absorption capacity of Gmelina arborea wood. Biotechnology, 7: 351-353.

Prestemon DR. 1994. Selection and use of preservative-treated wood. The Iowa Cooperative Extension Services, Programs and Policies. File: Forestry 8 Pm-1033.

Sarker PK, Rahman MA, Bulbul MR, Das T, Ilias GNM. 2006. Standard test methods for wood preservatives by laboratory AgarBlock test. The International Research Group On Wood Preservation, Doc. No. IRG/WP06-20350. Paper for the $37^{\text {th }}$ Annual Meeting, Tromso: Norway; 18-22.

Sundman CE. 1990. Tests with ammoniacal copper and alkyl ammonium compounds as wood preservatives. International Research Group on Wood Preservation. Doc. No. IRG/WP/90/3299.

Temiz A, Yildiz UC. 2006. The use of Modulus of Elasticity and Modulus of Rupture to assess wood decay in laboratory soil-bed test. The International Research Group On Wood Preservation, Doc. No. IRG/WP0620338. Paper for the $37^{\text {th }}$ Annual Meeting, Tromso: Norway; 18-22.

Usta I, Takata K, Doi S. 2006. Comparative studies of natural durability of Japanese Cedar (Cryptomeria japonica D. Don.) among the geographic cultivates. The International Research Group On Wood Preservation, Doc. No. IRG/WP06-10592. (Paper for the $37^{\text {th }}$ Annual Meeting, Tromso: Norway; 18-22. 
Viitanen $\mathrm{H}$, Metsa-Kortelainen S, Laakso $\mathrm{T}$. 2006. Resistance of pine and spruce heartwood against decay: The effect of wood chemical composition and coating with water-borne wood oil product. The International Research Group On Wood Preservation, Doc. No. IRG/WP06-10597. Paper for the $37^{\text {th }}$ Annual Meeting, Tromso: Norway; 18-22.

Yildiz UC, Temiz A. 2006. The use of modulus of elasticity and modulus of rupture to assess wood decay in laboratory soil-bed test. The International
Research Group On Wood Preservation, Doc. No. IRG/WP06-20338. Paper for the $37^{\text {th }}$ Annual Meeting, Tromso: Norway; 18-22.

Yildiz UC, Temiz A, Engin ED, Gezer D, Yildiz S. 2004. Effects of the wood preservatives on mechanical properties of yellow pine (Pinus sylvestris L.) wood. Building and Environment, 39: 10711075. 